\title{
An Economic Evaluation of Potential of Stress Tolerant Rice Varieties
}

\author{
B. Nirmala*, Amtul Waris, P. Muthuraman and N. Sunder Rao \\ ICAR-Indian Institute of Rice Research, Hyderabad-500030, India \\ *Corresponding author
}

Keywords

Rice, Stress tolerance, Yield advantage

Article Info

Accepted: 07 December 2018 Available Online: 10 January 2019

\section{A B S T R A C T}

Rice, the staple food crop of India contributes to 'No Poverty' and 'Zero Hunger' Sustainable Development Goals. Adoption of varieties particularly resistant to climate stress is among the most cited adaptation measures for on-farm livelihood adaptation strategies, therefore the present study was undertaken to analyse the farm-level economic impact of selected biotic and abiotic stress tolerant rice varieties, viz., Improved Samba Mahsuri (Bacterial Leaf Blight Resistant), Telangana Sona (Late sowings) and DRR Dhan 44 (Drought). Nalgonda and Mahboobnagar districts of Telangana and Karur district of Tamil Nadu were selected for the study, as these stress tolerant varieties are being popularised in these districts. An ex-post impact analysis was applied to measure the farm level economic impact of stress tolerant rice varieties. Results from the farm level survey in 2016 show that the farmers could realize a yield advantage of $12 \%$ through the yield loss averted by adoption of Improved Samba Mahsuri. The BCR for Improved Samba Mahsuri was higher (1.2) in comparison to Samba Mahsuri (1.1). The BCR of DRR Dhan 44 was 1.5, whereas for Samba Mahsuri, it was 1.3, which implies that the yield reduction due to drought was averted and the net returns were higher with the adoption of DRR Dhan 44. In order to encourage widespread adoption of stress tolerant rice varieties, dissemination activities must be accelerated. This requires proper targeting of beneficiaries in stress affected areas, complemented by training of farmers in sustainable agricultural practices.

\section{Introduction}

Food and agriculture is important to the achievement of the 2030 Agenda for Sustainable Development ranging from goals to ending poverty and hunger (SDG1 and SDG2), addressing climate change (SDG11) and sustaining natural resources (FAO, 2016). Thus a viable and sustainable agricultural sector has the potential to not only address hunger and malnutrition but several other challenges including poverty; water and energy use; climate change; and unsustainable production and consumption. Agriculture is the basis and pre-condition for sustainable development. Agriculture provides basic and important materials for global sustainable development (Gang, 2007). India, the second most populous country with 1.3 billion inhabitants, is expected to surpass China in next seven years. As rising incomes improve access to food for more and more people, 
current trend of slow regional growth in food production due to changing temperatures and precipitation patterns, along with increased weather variability, will present challenges for meeting the food demand sustainably. There is also limited scope for expansion of crop and pastureland, continuing competition for productive resources, and growing water scarcity (David, 2017). This great challenge cannot be understood without sustainability (Altieri, 2017). "A sustainable agriculture is one that, over the long term, enhances environmental quality and the resource base on which agriculture depends; provides for basic human food and fiber needs; is economically viable; and enhances the quality of life for farmers and society as a whole" (Anon., 1989).

Sustainable agriculture is challenged by biotic and abiotic stresses. Plants are faced with numerous biotic stresses and adverse environmental conditions. They respond to these stresses through several morphological, biochemical, and molecular mechanisms and evidence suggests that there are interactions among their respective signalling pathways (Nejat, 2017). Biotic stresses in plants are caused by pests, parasites and pathogens, which are known since ancient times. Fungi, bacteria, nematodes and viruses are the pathogens primarily responsible for plant diseases (Gimenez, 2018). Drought, cold and salinity are included under abiotic stress. Abiotic stress conditions cause extensive losses to agricultural production worldwide (Ron, 2006). The abiotic stress such as drought directly affects plant-pest interactions by altering plant physiology and defence responses (Scherm and Coakley, 2003). Additionally, drought also enhances competitive interactions of weeds on crops as several weeds exhibit enhanced water use efficiency than crops (Patterson, 1995; Ziska et al., 2010; Valerio et al., 2013). Drought stress is highly damaging during the reproductive stage, specifically during flowering, but even mild drought in other stages can also lead to big losses (Liu et al., 2006). To mitigate losses due to drought, new drought-tolerant high yielding rice varieties need to be developed, as farmers face a dilemma in choosing between a high-yielding variety and a drought-tolerant one with a yield penalty (Yamano et al., 2018). Some pests may alter plant response to abiotic stress factors (Prachi, 2017).

Rice is the staple food crop of the world. About 900 million of the world's poor depend on rice as producers or consumers and the global demand for rice will increase to 536551 million tons in 2030 (Rice, 2017). The status of rice production in India is directly related to the food security and sustainable development. Rice is prone to various biotic and abiotic stresses, which pose threat to the rice production and food security. The adoption of variety with strong tolerance is a main adaptation measure of farmers, which can mitigate the harmful effects of climate change on rice (Wu, 2004; Wang, 2005). Increased farm productivity of rice farmers can be brought about by improved rice varieties with higher yield, better quality and market value, and tolerance to biotic and abiotic stresses (drought, floods, extreme temperatures, and pests and diseases). Changing to crop varieties that are resistant to climate stress is among the most cited adaptation measures for on-farm and non-farm livelihood adaptation strategies (Westengen et al., 2014).

This study examines the farm level economic impact of selected biotic and abiotic stress tolerant rice varieties (Table 1). Improved samba mahsuri, a Bacterial Leaf Blight (BLB) tolerant rice variety was selected for the study under biotic stress. DRR Dhan 44, a drought tolerant rice variety and Telanga Sona, a variety suitable for late sowings, were selected under abiotic stress. 


\section{Materials and Methods}

\section{The study region}

The general agriculture profile of the selected districts is depicted in Table 2. Mahboobnagar is a district in the Indian state of Telangana. Mahboobnagar is also known as 'Palamoor'. The district shares boundaries with Vikarabad, Rangareddy, Nagarkurnool, Wanaparthy and Jogulamba Gadwal districts and with Karnataka state. Mahabubnagar occupies $18,47,000$ ha with nearly $17 \%$ of the area under forests. The gross cropped area is $9,03,453$ ha with a cropping intensity of $108 \%$. Rice is grown on an area of 9,6278 ha and constitutes $10.66 \%$ of the Gross cropped area of the district. Nalgonda district is in the Telangana state of India. The district shares boundaries with Suryapet, Rangareddy, Yadadri, and Nagarkurnool districts, and with the state boundary of Andhra Pradesh. Nalgonda has 6,69,164 ha Gross cropped area with Net sown area of 5,70,978 ha and a cropping intensity of $117 \%$. The percent Gross rice area to Gross cropped area is $32 \%$.

Karur is a district located very centrally along the Cauvery and Amaravathi rivers in the Indian state of Tamil Nadu. The Gross and Net cropped area of the district during 201617 were 47462.47 and 46840.92 respectively with a cropping intensity of $101 \%$. The Gross area under rice contributed to $28 \%$ to the Gross cropped area of the district. The average annual rainfall ranged from $446.2 \mathrm{~mm}$ for Mahbubnagar to $660.5 \mathrm{~mm}$ for Nalgonda during the year 2016. Karur received average annual rainfall of $652.2 \mathrm{~mm}$ in 2016 .

\section{Profile of the selected rice varieties}

\section{Improved Sambha Mahsuri}

Samba Mahsuri (BPT5204) is a medium slender grain indica rice variety that is very popular with farmers and consumers across
India because of its high yield and excellent cooking quality. However, the variety is susceptible to several diseases and pests, including bacterial blight (BB) (Sundaram, 2008). Improved Samba Mahsuri (ISM) is a high yielding fine grain rice variety. In a collaborative project, scientists from CSIRCCMB and the ICAR-Indian Institute of Rice Research [IIRR, erstwhile Directorate of Rice Research (DRR)], bred this variety. The variety was developed using Marker assisted selection and has three major bacterial blight resistance genes Xa21, xa13 and xa5. All India Coordinated Rice Improved Project (AICRIP) conducted trails in multiple locations across India, and found positive results for resistance to bacterial blight. After successful laboratory tests, field trials started in 2005-06 in multilocation settings. With the field trials also proving successful, the ISM variety was released commercially in 2008 in several states, mainly in BLB endemic areas in Andhra Pradesh, Tamil Nadu and Karnataka under the name ISM. It was also licensed to Sri Biotech to market during the 2011-12 kharif season with the commercial name SRI BIO226. The company discontinued marketing it after 2012, as it was not part of its core business. Since 2012, CSIR -CCMB and ICAR - IIRR have implemented a project called BLIGHT OUT under the CSIR-800 scheme for the popularisation of ISM in all the BLB prone areas (Amarender, 2017) (Table $3)$.

\section{DRR Dhan 44}

Drought is the most important abiotic stress and is also a priority for sustainable agricultural development. The drought tolerance in rice is very complex, controlled by quantitative traits and is the very reason for poor progress of breeding under drought prone rainfed and low land areas. Rice variety DRR Dhan 44 (IET 22081) is released in the year 2014 for cultivation under irrigated conditions 
for the states of Uttarakhand, Haryana and Bihar. DRR Dhan 44 was developed by Indian Institute of Rice Research, Rajendranagar, Hyderabad, under the IRRI-India project on Stress Tolerant Rice for Asia and South Africa (STRASA). Though DRR Dhan 44 is released for cultivation under irrigated conditions, it is characterized by very high yield under limited water conditions. It is an early duration; drought tolerant, high yielding and long slender variety suited both for transplanted and direct seeded aerobic cultivation with good weed competitive ability. It has desirable grain quality characteristics and several other desirable traits. DRR Dhan 44 is resistant to blast, moderate resistant to other diseases and pests such as bacterial leaf blight and plant hoppers. It has tolerance to drought at reproductive stage and also has high nutrient use efficiency.

\section{Telangana Sona}

Recently in Telangana state, RNR 15048 (Telangana Sona) has been released as short duration fine grain variety resistant to blast and is highly photosensitive in nature. It performs well even under low nitrogen level. Due to these reasons, this variety has been popularising in entire Telangana State, some parts of Andhra Pradesh and Karnataka states. Besides these advantages, the varietal performance in the farmer's field varied from location to location, with staggered sowing dates and under different nitrogen levels. The variety is suitable for late sowings. Delayed monsoon forces the farmers in Telangana to postpone sowings, resulting in an adverse impact on the yield.

\section{Data}

Purposive sampling method was adopted for the present study. Nalgonda and Mahboobnagar districts of Telangana and Karuru district of Tamil Nadu were selected for the study. The farm level impact of Telangana Sona was studied in Nalgonda district. Mahboobnagar experiences repeated drought leading to serious concerns over food security and hence the farm level impact of drought tolerant variety DRR Dhan 44 was studied.

The information used in this paper was obtained through field surveys, published sources and literature reviewing. Information on input-output details, cost of production, yields and output prices and other variables pertaining to the rainy season of 2016 was collected through a filed survey from the villages of three districts of Telangana and Tamil Nadu. These districts were Nalgonda, Mahboobnagar and Karur. In each village, focused group discussions were conducted to elicit information on the input-output and other details of rice production.

The stress tolerant varieties were used as risk mitigating technologies. These technologies might not raise yields in times where conditions are favourable, but they reduce the risk of very bad outcomes when negative shocks occur. Drought and pest resistant varieties are good source of risk mitigating technologies. While adoption may impact expected outcomes, these effects may not always be observed. A drought tolerant variety minimises yield losses in years of low rain but is otherwise the same as other varieties. Adoption increases expected yield, but if the farm survey takes place in a year with good rains, no benefit is observed. A similar problem applies to disease resistant variety.

Mahbubnagar and Nalgonda districts of Telangana have the highest drought frequency. Hence, drought tolerant variety DRR Dhan 44 was demonstrated in 2016 on 20 farmers' field, with Samba Mahsuri as local check variety. Telangana witnessed a delay in the onset of monsoon (thirteen days after the 
normal date) in 2016 and farmers could not take up sowings in time. Telangana sona, a variety suitable for late sowings was taken up by farmers of Nalgonda. Hence, 40 farmers from Nalgonda who cultivated both Telangana Sona and Samba Mahsuri were selected. Bacterial Leaf Blight incidence is common in Karur district of Tamil Nadu. Improved Samba Mahsuri (ISM) was demonstrated under the BLIGHT OUT scheme in the year 2016. Twenty farmers from Karur district who cultivated both ISM and Samba Mahsuri were selected. Thus, the study was conducted with 80 farmers.

\section{Methods of analysis}

An ex-post impact analysis (EPIAs) was applied to measure the farm level economic impact of stress tolerant rice varieties. The defining characteristic of ex-post impact analysis is their timing (Boardman et al., 2001) as EPIAs take place after a program or project has generated the intervention being assessed and sufficient time has elapsed and experience accumulated to assess the intervention's performance in terms of longerterm economic, social, and environmental consequences. EPIAs contribute primarily to accountability by demonstrating impact to donors and other stakeholders, and secondarily to learning about the effectiveness of agricultural research. With-and-without comparisons are the norm for estimating benefits in technology oriented EPIAs. The cost analysis was done and the economic indicators were worked out for the selected stress tolerant varieties. The cost analysis was done by using various cost concepts.

\section{Results and Discussion}

A comparison of the yield performance of stress tolerant varieties with the local check Samba Mahsuri, which is a mega variety, is presented in Figure 1. The yield advantage of stress tolerant varieties ranged from 7.1 to 9.1 quintal per hectare. The highest yield realised was for Telangana sona, wherein the farmers could obtain 6.8 tons per hectare in comparison with Samba Mahsuri which yielded 5.9 tons per hectare, on an average.

The incidence of BLB disease in the year 2016 resulted in yield loss in Samba Mahsuri to the tune of $12 \%$. This yield loss could have been averted with the adoption of BLB resistant Improved Samba Mahsuri, which is one of the risk mitigating technologies. These technologies might not raise yields in times where conditions are favourable, but they reduce the risk of very bad outcomes when negative shocks occur. ICRISAT introduced DRR Dhan 44 on a trial basis in eight Agency villages of Vara Ramachandrapuram mandal in East Godavari district in 2017. DRR Dhan 44 has fared better than MTU 1001, a common variety in this area. In addition to yielding four bags more than other varieties, Dhan 44 has withstood well the long dry spells (The Hindu, 2018). The cost of production of a crop is considered at three different levels viz., Cost A, Cost B and Cost C. The concept of costs is followed to work out the cost of cultivation of crops by the Directorate of Economics and Statistics, Government of India. Controlling costs and increasing productivity are important factors that will determine the profitability of a farm. Various cost concepts involved in the cultivation of rice are presented in Table 4 . The cost analysis of the selected rice varieties indicated that the Cost A (Operational costs) incurred on the stress tolerant rice varieties was comparatively less on Telangana sona and Improved Samba Mahsuri. In case of DRR Dhan 44, the Cost A incurred was almost same as Samba Mahsuri. A comparison of Cost C, which includes $10 \%$ managerial cost for the farmer indicated that the costs incurred on DRR Dhan 44 and Samba Mahsuri were almost same. Economic indicators of cultivation of the stress tolerant 
rice varieties are presented in Table 5 . The net returns obtained by the sample farmers were higher in DRR Dhan 44(Rs.27398/ha) in comparison to the Samba Mahsuri (Rs.16274/ha). Nurunnaher et al., (2003) stated that the Benefit-Cost Ratio is the ratio of the present worth of the gross benefit to the present worth of the gross cost. It refers to the return per monetary unit of cash cost. This ratio is a common technique used to evaluate the profitability of farming in relation to farm management.

Table.1 Rice varieties selected for various biotic and abiotic stress

\begin{tabular}{|l|l|}
\hline Stress & Variety selected \\
\hline BLB infestation (Biotic stress) & Improved Samba Mahsuri \\
\hline Drought (Abiotic stress) & DRR Dhan 44 \\
\hline Late sowing (Abiotic stress) & Telangana Sona \\
\hline
\end{tabular}

Table.2 General agriculture profile of the selected districts

\begin{tabular}{|l|c|c|c|c|c|l|l|}
\hline District & $\begin{array}{c}\text { Net } \\
\text { Sown } \\
\text { Area } \\
\text { (ha) }\end{array}$ & $\begin{array}{c}\text { Total } \\
\text { Cropped } \\
\text { Area } \\
\text { (ha) }\end{array}$ & $\begin{array}{c}\text { Cropping } \\
\text { intensity } \\
(\mathbf{\%})\end{array}$ & $\begin{array}{c}\text { Rice Area } \\
\text { (ha) }\end{array}$ & $\begin{array}{c}\text { \% Gross } \\
\text { rice area to } \\
\text { gross } \\
\text { cropped } \\
\text { area }\end{array}$ & $\begin{array}{l}\text { Rainfall } \\
\mathbf{2 0 1 6}\end{array}$ & (mm) \\
\hline $\begin{array}{l}\text { Mahabubnagar } \\
\text { (2015-16) }\end{array}$ & 835611 & 903453 & 108.12 & 96278 & 10.66 & 446.2 & \\
\hline $\begin{array}{l}\text { Nalgonda (2015- } \\
\text { 16) }\end{array}$ & 570978 & 669164 & 117.20 & 212730 & 31.79 & 660.5 & \\
\hline Karur (2016-17) & 46840.92 & 47462.47 & 101.33 & 13276 & 27.97 & 652.2 & \\
\hline
\end{tabular}

Table.3 Characteristics of rice varieties

\begin{tabular}{|l|l|l|l|l|l|l|}
\hline Variety & Name & $\begin{array}{l}\text { Year of } \\
\text { release }\end{array}$ & $\begin{array}{l}\text { Duration } \\
\text { (days) }\end{array}$ & $\begin{array}{l}\text { Grain } \\
\text { quality }\end{array}$ & $\begin{array}{l}\text { Breeding } \\
\text { method }\end{array}$ & $\begin{array}{l}\text { Yield } \\
\text { (t/ha) }\end{array}$ \\
\hline RP Bio 226 & Improved samba mahsuri & 2007 & 140 & Fine & $\begin{array}{l}\text { Marker assisted } \\
\text { selection }\end{array}$ & $5.5-6$ \\
\hline IET 22081 & DRR Dhan 44 & 2014 & 115 & Fine & Conventional & $6-6.5$ \\
\hline RNR 15048 & Telangana sona & 2015 & 125 & Fine & Conventional & $6.5-7$ \\
\hline
\end{tabular}

Table.4 Cost of cultivation of selected rice varieties on different cost concepts basis

\begin{tabular}{|l|r|l|l|r|r|r|}
\hline Cost & \multicolumn{1}{|l|}{$\begin{array}{l}\text { Telangana } \\
\text { sona }\end{array}$} & $\begin{array}{l}\text { Samba } \\
\text { Mahsuri }\end{array}$ & $\begin{array}{l}\text { DRR } \\
\text { Dhan 44 }\end{array}$ & $\begin{array}{l}\text { Samba } \\
\text { Mahsuri }\end{array}$ & ISM & \multicolumn{1}{|l}{$\begin{array}{l}\text { Samba } \\
\text { Mahsuri }\end{array}$} \\
\hline Cost A & 50657.7 & 53264.03 & 46317.63 & 45702.38 & 61899.5 & 64815.25 \\
\hline Cost B & 58660.2 & 61266.53 & 55186.38 & 54571.13 & 103259.5 & 106175.3 \\
\hline Cost C & 64526.22 & 67393.13 & 60704.98 & 60028.25 & 113585.5 & 116792.8 \\
\hline
\end{tabular}


Table.5 Economic indicators of stress tolerant rice varieties

\begin{tabular}{|c|c|c|c|c|c|c|}
\hline Particulars & $\begin{array}{l}\text { Telangana } \\
\text { sona }\end{array}$ & $\begin{array}{l}\text { Samba } \\
\text { mahsuri }\end{array}$ & ISM & $\begin{array}{l}\text { Samba } \\
\text { Mahsuri }\end{array}$ & DRR Dhan 44 & $\begin{array}{l}\text { Samba } \\
\text { Mahsuri }\end{array}$ \\
\hline Total costs & 58660.2 & 57781.96 & 103259.5 & 106175.3 & 55186.38 & 54571.13 \\
\hline Gross returns & 113500.7 & 112439.2 & 122675 & 114562.5 & 82584.00 & 70845.00 \\
\hline Net returns & 54840.5 & 54657.24 & 19415.5 & 8387.25 & 27397.63 & 16273.88 \\
\hline BC ratio & 1.9 & 1.9 & 1.2 & 1.1 & 1.5 & 1.3 \\
\hline
\end{tabular}

Fig.1 Performance of stress tolerant rice varieties

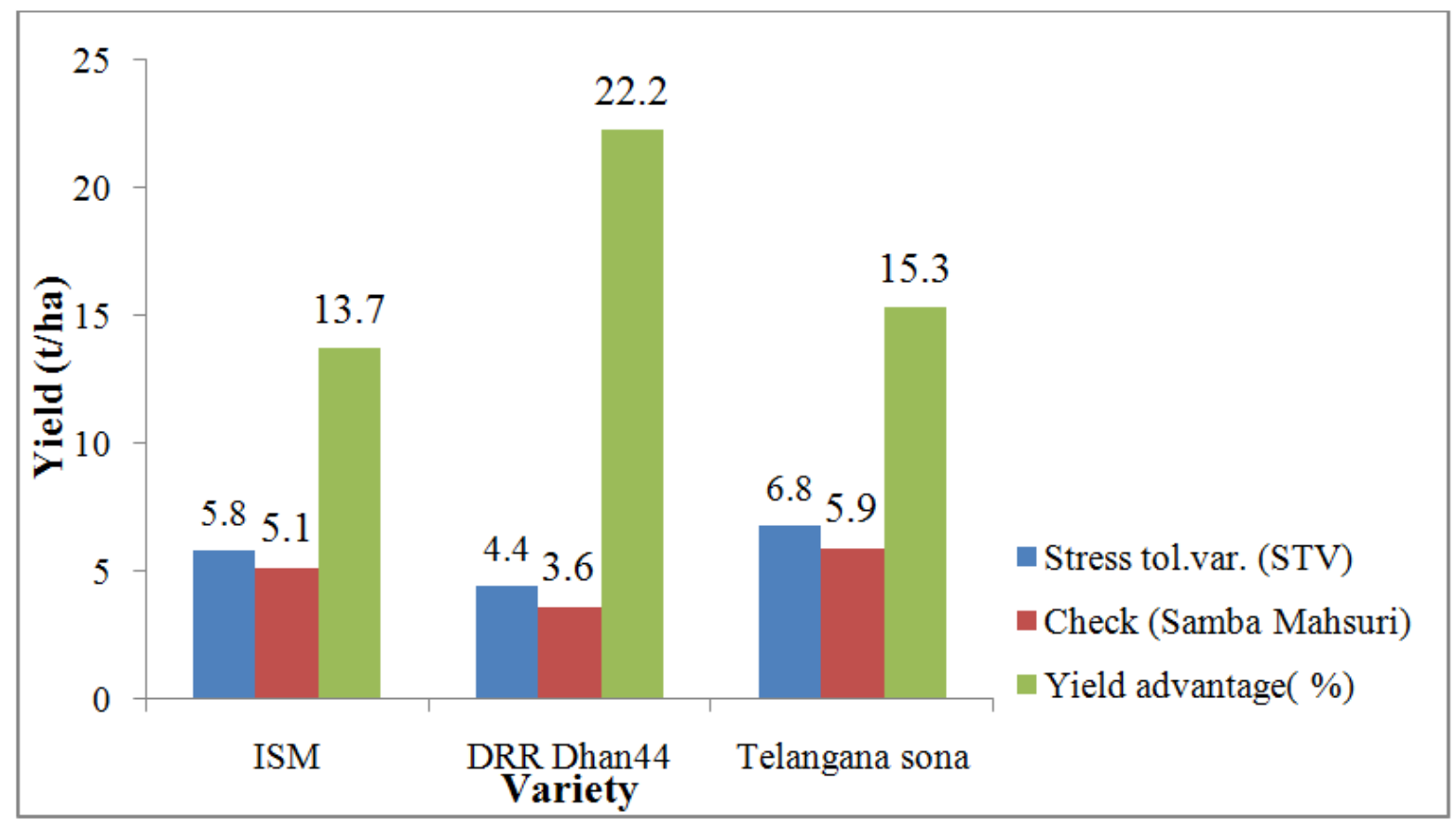

The benefit cost ratio (BCR) for Telangana sona and Samba Mahsuri were same. It could be stated that, though Telangana sona had a yield advantage of $15 \%$ over the Samba Mahsuri, the out price offered to farmers by the millers and traders was lower by Rs. 216 /quintal, than the Samba Mahsuri. The BCR for Improved samba mahsuri was higher (1.2) in comparison to Samba Mahsuri (1.1). The BCR of DRR Dhan 44 was 1.5, whereas for Samba Mahsuri, it was 1.3, which implies that the yield reduction due to drought was averted and the net returns were higher with the adoption of DRR Dhan 44.
In conclusion, the farm level economic impact of stress tolerant rice varieties indicated that, the adoption of these varieties averted the yield loss due to biotic and abiotic stresses and improved the income of the adopter farmers. In order to encourage widespread adoption of stress tolerant rice varieties, dissemination activities must be improved. This requires proper targeting of beneficiaries, dissemination of stress tolerant rice varieties in stress prone areas, complemented by training in sustainable agricultural practices. Proper targeting and training of beneficiaries of interventions can 
help improve exposure and adoption and hence improve productivity. Persistent dissemination efforts are required for popularization of these stress tolerant rice varieties among farmers along with supply of improved seeds.

\section{References}

Alain, D.J., Andrew, D., and Elisabeth, S. (2010). Paper presented in workshop "Increasing the rigor of ex-post impact assessment of agricultural research: A discussion on estimating treatment effects", organized by the CGIAR Standing Panel on Impact Assessment, SPIA, on Saturday October 2, 2010, Berkeley.

Altieri, M.A., Nicholls, C.I., and Montalba, R. (2017). Technological Approaches to Sustainable Agriculture at a Crossroads: An Agroecological Perspective. Sustainability, 9, 349.

Amarender, R.A., (2017). The case of improved samba Mahsuri. Economic and Political Weekly, 52(39),17-19.

Boardman A.E., Greenberg, D.H., Vining A.R., and Weimer, D.L., (2001). CostBenefit Analysis: Concepts and Practice. Upper Saddle River. Prentice Hall: New Jersey. USA.

Coakley, S. M., Scherm, H., and Chakraborty, S. (1999). Climate change and plant disease management. Annu. Rev. Phytopathol, 37, 399-426. doi: 10.1146/ annurev.phyto.37.1.399

David, R., Timothy, S., and Keith, W. (2017). World Population Day 2017: IFPRI models impact of population growth on demand for food. IFPRI's Global Food Policy Report.

FAO (2016). Food and Agriculture: Key to Achieving the 2030 Agenda for Sustainable Development; Food and Agriculture Organization of the United Nations: Rome, Italy.
Gang, Wu., Chuang, Z., Li-Ye, Chu., and Hong-Bo, Shao. (2007). Responses of higher plants to abiotic stresses and agricultural sustainable development. Journal of Plant Interactions, 2:3, 135147, $\quad$ DOI: $\quad 10.1080 / 174291$ 40701586357

Gimenez, E. I.D., Maria, S., and Francisco, M., (2018). Worldwide Research on Plant Defense against Biotic Stresses as Improvement for Sustainable Agriculture. Sustainability, 10, 391. doi:10.3390/su10020391

https://www.thehindu.com/news/national/and hra-pradesh/new-paddy-varietybursts-onto-east-godavari-agencyscene/article24176221.ece

Liu, J.X., Liao, D.Q., Oane, R., Estenor, L., Yang, X.E., Li, Z.C., and Bennett, J. (2006). Genetic variation in the sensitivity of anther dehiscence to drought stress in rice. Field Crops Res., 97:87-100.

Nejat, N.,\& Mantri, N.(2017) Plant immune system: Crosstalk between responses to biotic and abiotic stresses the missing link in understanding plant defense. Curr. Issues Mol. Biol., 23, $1-16$.

Nurunnaher, K.M., Rahman and Ali, M.H.(2003) Productivity and Efficiency Measurement of Rice Production by Member and Nonmember Farmers in Selected Cooperative Societies of Bangladesh. Economic Affairs, 48(4).220.

Patterson, D. T. (1995). Effects of environmental stress on weed/crop interaction. Weed Sci. 43, 483-490.

Prachi, P., Vadivelmurugan, I., Muthukumar, V.B., and Muthappa, S.K. (2017). Impact of Combined Abiotic and Biotic Stresses on Plant Growth and Avenues for Crop Improvement by Exploiting Physio-morphological Traits. Front. Plant Sci., 18 April 2017 
https://doi.org/10.3389/fpls.2017.0053 7

Raju, V.T., and Rao, D.V.S. (1990). Economics of Farm Production and Management. Oxford and IBH Publishing Co.Pvt.Ltd., New Delhi.

RICE (2017). CGIAR Research Program RICE contributions to the United Nations Sustainable Development Goals http://ricecrp.org/wp-content/ uploads/2017/03/RICE-and-SDGs.pdf

Ron, M. (2006) Abiotic stress, the field environment and stress combination TRENDS in Plant Science Vol.11 No.1 15-19

Scherm, H., and Coakley, S. M. (2003). Plant pathogens in a changing world. Australas. Plant Pathol. 32, 157-165. doi: 10.1071/AP03015

Sundaram,R.M., Vishnupriya, M.R., Biradar, S.K., Laha, G.S., Reddy, G.A., Rani, N.S., Sharma, N.P., and Sonti, R.V. (2008). Marker assisted introgression of bacterial blight resistance in Samba Mahsuri, an elite indica rice variety. Euphytica, 160 (3), 411-422.

Valerio, M., Lovelli, S., Perniola, M., Tommaso, D. T., and Ziska, L. (2013). The role of water availability on weed-crop interactions in processing tomato for southern Italy. Acta Agric. Scand. Sect. B 63, 62-68. doi: 10.1080/09064710.2012. 715184
Walker, T., Maredia, M., Kelley, T., La Rovere, R., Templeton, D., Thiele, G., and Douthwaite, B. (2008). Strategic Guidance for Ex Post Impact Assessment of Agricultural Research. Report prepared for the Standing Panel on Impact Assessment, CGIAR Science Council. Science Council Secretariat: Rome, Italy.

Weil R.R.(1990). Defining and using the concept of sustainability J. Agron. Educ., 19(2) 126-130

Westengen, O.T., and Brysting, A.K. (2014). Crop adaptation to climate change in the semiarid zone in Tanzania: the role of genetic resources and seed systems. Agriculture and Food Security, 3(3).

Yamano, T., Dar, M.H,, Panda, A., Gupta, I., Malabayabas, M.L., and Kelly, E.( 2018). Impact and adoption of riskreducing drought-tolerant rice in India, 3ie Impact Evaluation Report 72. New Delhi: International Initiative for Impact Evaluation (3ie).

Ziska, L. H., Tomecek, M. B., and Gealy, D. R. (2010). Evaluation of competitive ability between cultivated and red weedy rice as a function of recent and projected increases in atmospheric CO2. Agron. J. 102, 118-123. doi: $10.2134 /$ agronj2009.0205

\section{How to cite this article:}

Nirmala, B., Amtul Waris, P. Muthuraman and Sunder Rao, N. 2019. An Economic Evaluation of Potential of Stress Tolerant Rice Varieties. Int.J.Curr.Microbiol.App.Sci. 8(01): 576-584. doi: https://doi.org/10.20546/ijcmas.2019.801.064 